\title{
IgA Phospholipid Unit
}

National Cancer Institute

\section{Source}

National Cancer Institute. IgA Phospholipid Unit. NCI Thesaurus. Code C122202.

A unit for semiquantitative measurement of IgA autoantibodies to proteins associated with negatively charged phospholipids evaluated ag ainst an established reference standard. 